\title{
Unambitious Average Syndrome? The Ambiguity of Minimum Service Standards (MSS) in a Decentralised Polity
}

\author{
Mohammad Roudo ${ }^{1}$ \\ Ministry of National Development Planning/BAPPENAS
}

\begin{abstract}
How can performance management influence public sector agencies to improve their performance? This question has long been the subject of intense discussion among scholars It is often the case that public sector units have no motivation to improve beyond the minimum level required to stay safe and can also result in unambitious average syndrome.

A similar phenomenon potential to arise with the introduction of the Minimum Service Standards (MSS) for local authorities within Indonesia's decentralised system. Through the decentralisation policy, which was launched in 1999, the central government has devolved most public service decision-making to local authorities. As a consequence of this policy, inequality has grown, reflecting different capacities and motivations of local governments. Yet, the central government has (in principle) a reserve power to intervene and enforce these minimum standards. Thus, instead of a set target or rank for local government, MSS was introduced as a form of compromise between the central and local governments in relation to the minimum quality of services in health and education that should be delivered by local governments.
\end{abstract}

This paper attempts to assess the influence of public sector performance management on the motivation of local public-sector agencies to improve their performance. There are two main research questions. Firstly, what is the influence of MSS on the motivation of public sector agencies to improve their performance in delivering services? Secondly, how far does the concept of an unambitious average syndrome explain the outcomes attained? Semistructured interviews with 80 informants in central and local government, as well as scholars, non-government organisations and international agencies were used in data collection, with thematic analysis used for data analysis.

In terms of the results, the influence of MSS on the motivation of local governments to improve their performance hardly fits with the idea of the 'unambitious average syndrome'. MSS seems only to motivate improvements in performance among those local governments whose current achievement fall just below the required standard. They are motivated only to pass and deliver just above the required standard. MSS, however, does not appear to motivate local governments delivering either above or well below the standards.

Keywords: Minimum Service Standards (MSS), Unambitious Average Syndrome, Local Government Performance, Motivation, Public Sector 


\section{Unambitious Average Syndrome? The Ambiguity of Minimum Service Standards (MSS) in a Decentralised Polity}

Mohammad Roudo, BAPPENAS

\section{Introduction}

How can performance management influence public sector agencies to improve their performance? This question has long been the subject of intense discussion among scholars (see De Bruijn, 2007; Van Dooren et al., 2010; Talbott, 2010). Scholars such as Mullins (2008), Van Dooren et al. (2010), Greenberg (2011) and Moorhead and Griffin (2012) argued that performance management may influence the performance of public sector agencies by influencing their behaviour, notably by changing their motivation. However, it has also been noted that this kind of performance management may potentially give rise to unintended negative consequences known by some scholars as the performance paradox or dysfunctional effects of performance management (see Smith, 1995; Bevan and Hood, 2006; Seddon, 2008).

These negative influences can come in various guises and range from gaming to the phenomenon of the unambitious average syndrome, with the potential to demotivate units in the public sector from continually improving their performance. These effects also have the potential to arise following the introduction and implementation of Minimum Service Standards (MSS) in Indonesia's decentralised system. Instead of increasing the motivation of local governments to improve their performance in delivering services, particularly in basic services such as health and education, MSS may potentially result in their demotivation.

This paper attempts to assess the influence of public performance management on the motivation of public agencies to improve their performance. This research addresses the influence of MSS on the motivation of local governments to improve their performance in relation to the delivery of services. It attempts to answer two main research questions, as follows: 1) What is the influence of MSS on the motivation of public sector agencies (local governments) to improve their performance in delivering services? 2) How far does the concept of unambitious average syndrome explain the outcomes attained?

This paper comprises three parts. The first part defines the concept of MSS from the perspectives of both the literature on performance management and the practice of MSS within the Indonesian decentralised system. The second part contains a brief review of the literature on performance management and its influence on the motivation of units in the public sector. The discussion includes the idea of the unambitious average syndrome in the context of imposing performance management. The third part contains empirical evidence from eight districts and cities in Indonesia on the extent to which MSS increases their motivation to improve their performance in delivering services, particularly in the health sector, and how the concept of the unambitious average syndrome could explain this phenomenon.

\section{Defining MSS}

The concept of MSS is defined from two points of views. A definition derived from contemporary literature and current international practice of performance management in the public sector is presented first. There is then a definition based on the unique practice of MSS in the Indonesian decentralised system.

\subsection{MSS from Literature and International Practices of Performance Management}

From perspective of literature and international practices of performance management in the public sector, the concept of MSS can be defined as a set of quality standards or assurances, as one type of performance management regime in the public sector. Bouckaert (1995), in the context of public services in European countries, argues that quality standards refer to qualitative and quantitative measurements which can be assigned and 
are meaningful for observing the particular quality of services that are delivered to people. They are meaningful as they cause values to change and increase the sensibility and set new perceptions in the interests of people (Williamson, 1992). This is why, in Italy, the concept of standards is employed to express the values of the rights of consumers or users in relation to particular services, and is used as the basis for public complaints (Schiavo, 2000).

The practice of establishing a set of quality standards for public services was introduced in the UK in 1991 by the then prime minister, John Major, in the form of the Citizen's Charter initiative. The idea was subsequently partly adopted in a number of European countries such as France, Belgium and Italy, in the latter through the Carta Dei Servizi under Prime Minister Mr Ciampi in 1993 (Kuuttiniemi and Virtanen, 1998, cited in Schiavo 2000, p. 682), as well as in developing countries, such as via the MSS in Indonesia and a performance management system in South Africa (Ferrazzi, 2005). These standards served as the basis for providers to conduct self-assessments of their services and to examine the needs of their staff and the requirement(s) to establish services, in addition to the most important aspect, that of the expectations of the services by their users (Gaster, 1995).

In terms of a concept, quality standards can also be distinguished to a common target. Firstly, quality standards capture more specific targets which reflect an organisation's commitment to develop or improve the quality of its services. Devon County Council (1993, cited in Gaster 1995, p. 96) notes that quality standards refer to a clear and explicit indication of the types of services that should be provided, the activities that should take place and the expectations of how much, how frequently and how quickly they should be delivered. These may be expressed in terms of percentages, numbers, frequencies, costs or using a range of other quantitative and qualitative indicators. Secondly, there are greater options when seeking to apply targets for quality standards. While targets are commonly set in terms of an ideal target or level of achievement, in quality standards or assurance, they may also take the form of a realistic or minimum target (Gaster, 1995). Schiavo (2000) also added that certain choices can be made in relation to setting standards which can influence their effectiveness and acceptability such as average or minimum standards.

However, it remains difficult to derive an exact definition of a minimum standard in the domain of public administration. Only a few references explain the concept as referring to the obligation of the object, whether in relation to an individual or an organisation, to exceed a minimum point or value. This individual or organisation is not permitted to deliver below this level. In other words, they are required to just pass a threshold level. One important idea about minimum standards can be generated from a technical conversation on how services are to be supplied. In the case of water supply, for instance, Eide (1972) used the term to define the minimum amount of water that should be distributed to meet the needs of each person. He added that whether the target is self-imposed or applied by other parties, the distribution of water cannot fall below the particular point that has been agreed (Eide, 1972).

In practice, in 2002, the UK government applied minimum standards to public services such as health, education and the welfare of children and young people. These are defined as a set of measurements and management targets to be met and achieved, designed to accommodate different types of fostering services and facilitate providers to develop their own approach to the provision of services to children and those who require them (Department of Health, 2002).

\subsection{MSS in Indonesia: Linking with Decentralisation Policy}

MSS has a unique definition in Indonesia in comparison to the current literature on and practices of performance management seen in the international context, although it is relatively similar in terms of requiring public sector units to pass and exceed particular points as a minimum required quality of services. The concept and practice of Indonesian MSS are closely related to the concept of decentralisation policy as a means of improving the quality of services.

A number of rationales lay behind Indonesia's introduction of a decentralisation policy in 1999 (see Aspinall and Feally, 2003; Firman, 2003; Schulze and Sjahrir, 2014). While some of these, such as reducing vertical imbalance and conflict, have the potential to deliver relatively satisfactory results, a big challenge remains in relation to enhancing the quality of public services and the capacity of the government to deliver them (see Mohammad, 2007; Mutaqin 
et al., 2016). Strategic Asia (2013) also notes this problem as an 'unfinished agenda' during the decade following the implementation of Indonesia's decentralisation.

The Indonesian central government introduced MSS in 2002 in response to the problem of the inconsistent coverage and quality of public services, especially in relation to health and primary education as basic public services. It was a breakthrough strategy, the key focus of which was on using decentralisation to both enhance basic public services across the regions and to reduce unequal service coverage and quality resulting from variations in the capacities of different regions. Here, MSS was designed to support and accelerate the achievement of one rationale of Indonesian decentralisation related to public services. On the one hand, MSS could accommodate mandates of decentralisation to continually improve the coverage and quality of public services. It was also seen as being able to overcome the problems of inequality in those services as a result of its putting in place a consistent set of standards across regions.

In addition, MSS seemed capable of overcoming the limitations of decentralisation policy whereby central government is limited in its capacity to directly intervene in the performance of local governments. This is why, in Indonesia's decentralised system, MSS is used as opposed to a system of targets or ranks. It is not easy to set targets or ranks in relation to managing the performance of local government to deliver services in the same way as that routinely exercised in more centralised systems, such as in the UK, where there is strong enforcement, control and scrutiny between the higher and lower levels of organisations and the government (see Bevan and Hood, 2006a; Hood, 2006).

The concept of Indonesian MSS is based on Law 32/2004, which was subsequently revised into Law 23/2014 and Government Regulation (GR) 65/2005. According to both regulations, MSS is defined as the minimum level of the type and quality of basic public services that should be received by each citizen. These basic public services, such as education, health and infrastructure, reflect the minimum level of citizens' socio-economic needs and rights that should be fulfilled by the government as part of their commitment to basic welfare, public order, national unity and national and international commitment, and are guaranteed by the constitution (Friedman, 2002; Haryanto, 2010). It is also known that MSS in Indonesia is tightly related to the obligatory functions of local government in the provision of public services. This local obligatory function refers to all 'concurrent functions' or 'shared competences' that are compulsorily implemented by each local government regardless of its capacities. Indonesia GR 38/2007 outlines 26 obligatory functions, but only a few of these, such as health, education and infrastructure, are classified as basic public services.

Among the many sectors covered by MSS, two main sectors, health and education, sit at the heart of the implementation of MSS and reflect the most essential basic services. Some examples of MSS indicators in the health sector are daily visits to pregnant mothers (K4 criteria), which saw 95\% achievement standards in 2015, and visits to pregnant mothers with complicated problems, with achievement standards of $80 \%$ for 2015 . The complete set of indicators can be seen in Figure 1 below.

Figure 1. Indicators of MSS in health sector

\begin{tabular}{|c|c|c|c|c|}
\hline No. & Types of Services & Indicators & Standards & Year \\
\hline \multirow[t]{14}{*}{1} & \multirow[t]{14}{*}{ Basic Treatment } & Daily visit of Pregnant Mother (K4 criteria) & $95 \%$ & 2015 \\
\hline & & Visit to Pregnant Mother with complicated problems & $80 \%$ & 2015 \\
\hline & & Aid from health workers or nurses & $90 \%$ & 2015 \\
\hline & & Service to mother after giving birth (childbed) & $90 \%$ & 2015 \\
\hline & & Neo-natal with complicated problems & $80 \%$ & 2010 \\
\hline & & Baby visits & $90 \%$ & 2010 \\
\hline & & Universal Child Immunization in Sub Districts & $100 \%$ & 2010 \\
\hline & & Services to under 5 years old children & $90 \%$ & 2010 \\
\hline & & $\begin{array}{l}\text { Provision of additional food to breast-milk to children } \\
\text { from poor families from } 6 \text { months into } 2 \text { years }\end{array}$ & $100 \%$ & 2010 \\
\hline & & $\begin{array}{l}\text { Services to under } 5 \text { years old children who are } \\
\text { malnutrition and get special treatment }\end{array}$ & $100 \%$ & 2010 \\
\hline & & Quality of health of students in primary schools & $100 \%$ & 2010 \\
\hline & & Member of active family planning & $70 \%$ & 2010 \\
\hline & & Observation and treatment to illness people & $100 \%$ & 2010 \\
\hline & & Basic health services to the poor families & $100 \%$ & 2015 \\
\hline
\end{tabular}




\begin{tabular}{|c|l|l|l|l|}
2 & Referral Treatment & $\begin{array}{l}\text { Recommended services to the poor families } \\
\text { First level of emergency services that should be } \\
\text { supported by health infrastructure in districts }\end{array}$ & $100 \%$ & 2015 \\
\hline 3 & $\begin{array}{l}\text { Epidemiology } \\
\text { Investigation and } \\
\text { cure to special } \\
\text { diseases }\end{array}$ & $\begin{array}{l}\text { Scope of Village or sub districts with special condition } \\
\text { through epidemiology investigations less than } 24 \text { hours }\end{array}$ & $100 \%$ & 2015 \\
\hline 4 & $\begin{array}{l}\text { Health promotion } \\
\text { and people } \\
\text { empowerment }\end{array}$ & Scope of Active Alert Village & $80 \%$ & 2015 \\
\hline
\end{tabular}

Source: Ministry of Health, 2008

\section{Performance Management and Its Influence on Organisations' Motivation to Improve Performance}

The understanding of the influence of MSS on increasing the motivation of local governments to improve their performance in delivering services in this paper follows the principal-agent framework and a number of concepts and organisational theories related to motivation. The model of principal-agent relations is actually an accountability model which seeks to explain how two actors, a principal and an agent, interact to achieve their own respective goals. Braun and Guston (2003) referred to it as the idea of delegation and exchange of resources. They also termed it the 'opportunism actor model' since it is assumed that every actor is selfish, thinking only about themselves and promoting their own self-interests and personal welfare (Braun and Guston, 2003). Similarly, Coleman (1990) highlighted it as 'the extension of [the] self-interests' of actors to achieve their goals by delegating tasks to those with greater capacities than themselves.

This is why, according to Peters (2001), Jacobides and Croson (2001) and Laffont and Martimort (2009), an understanding of the principal-agent theory and framework cannot be separated from the assumptions underpinning this theory. Firstly, both principals and agents act rationally and are driven by their legitimate self-interests and preferences. Principals are interested in ensuring that their mandates and objectives are delivered and completed by their agents. A principal, however, often lacks the necessary time, energy and information and also has limited capacity and expertise, meaning they require an agent's efforts in order to fulfil and maximise their interests and preferences.

To ensure agents remain accountable to the principal's interests, there needs to be a mechanism to which both the principal and agents are bound. Waterman and Meier (1998) noted that there should be a 'contract' between the principal and agents establishing what agents should do and what information should be received by principals. In our context, this contract is translated and converted into performance management. Simply, it can be noted that performance management has a role as a 'contract' that acts to bind both the principal and the agent under the principal-agent relationship. It acts to improve the principal's information, reduces information gaps between principals and agents, ensures agents act in the best interests of principals and prevents moral hazard on the part of agents (Hughes, 2003).

Mullins (2008), Van Dooren et al. (2010), Greenberg (2011) and Moorhead and Griffin (2012) argue that the importance of performance management can be seen in the extent to which it can positively change the behaviour of those individuals and organisations that it is intended to influence. In other words, as a contract, performance management has no use unless it positively influences individuals/organisations to improve their performance. Furthermore, two kinds of behaviours are expected from more compliant and motivated agents via performance management carried out under the principal-agent framework, as depicted in Figure 2. 
Figure 2. Performance management and influence on the behaviour of individuals/organisations

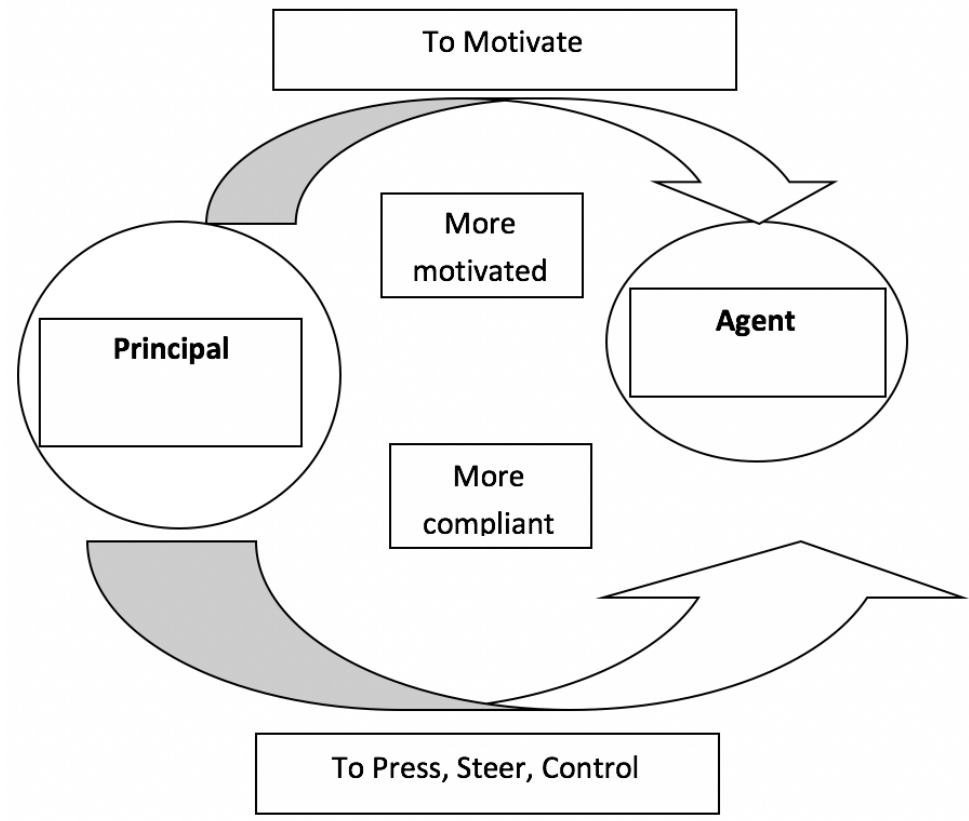

Source: Adapted and modified from Behn (2003), De Bruijn (2007), Van Dooren et al. (2010)

A more motivated local government is elaborated in order to answer the research questions. Encouraging agents to become more motivated to achieve the principal's interests is more positive in terms of its impact on behaviour in comparison to the first influence which seeks to increase compliance. In organisational theory, the phrase 'to motivate' simply means to endorse people to act and behave in a particular and intentional way. According to Huczynski and Buchanan (1991), Mullins (2008) and Moorhead and Griffin (2012), to motivate means to direct people to follow particular actions out of many possible alternative behaviours and then choose to continue this behaviour for a long period. In the principalagent framework, to motivate means that the principal should be able to direct agents to act, work and behave according to what is required and expected by the principal, without resorting to forcing them. It relates to the way in which a principal, whether this is a public manager or politician, takes their agents', workers' or staff's 'hearts and minds' along with their own interests (Crowther and Green, 2004). Mullins (2008) and Moorhead and Griffin (2012) add that the overall performance of an organisation is a function of its capacity/ability and motivation and the external factors which either support or impede them.

However, it is rare for there to be a change in motivation if this is not supported by an incentive. As such, it is external or internal factors that motivate people to act. In the public sector, the idea of incentive is related to that outlined by Taylor (1911), as a simple incentive or compensation model adopted from the practice of management in the private sector. It comprises rewards or compensation designed to motivate employees to perform well in tasks mandated by their leaders and managers as well as to achieve particular results in supporting the organisation's goals. Heinrich and Marschke (2010), Maynard (2011) and Burgess et al. (2012) note that incentives (rewards or compensation) aim to motivate both the organisation as a whole and the individuals that make up the organisation to make a significant contribution to the organisation's activities and the achievement of its goals. These incentives can be financial or non-financial measures and may be political, individual or organisational in form.

However, instead of increasing motivation, the application of performance management in the public sector, particularly in the form of targets/standards, may also give rise to a range of unintended negative and dysfunctional consequences. Bevan and Hood (2006) and Hood 
(2006) note some types of dysfunctional effects of targets/standards related to the motivation of units in the public sector: the ratchet and the threshold effects. ${ }^{1}$ Kalgin (2016) shows how public-sector performance management may be affected by data manipulation. The study identified the strategies of 'prudent' and 'reckless' bureaucrats ${ }^{2}$ in the context of regional government in Russia, proving the manipulation of performance measurement data as a negative consequence of the imposition of targets/standards (Kalgin, 2016). Other scholars such as Meyer and Gupta (1994) and Plant (2006) also note these negative consequences as a form of performance paradox.

Similar to both the ratchet and threshold effects and the notion of reckless and prudent bureaucrats, the 'unambitious syndrome' can be identified. The phrase 'unambitious average' was commonly used by auditors in the UK during the 1990s and 2000s. Auditors would use it in relation to units in the public sector that had no motivation to improve their performance beyond their targets. These units preferred to remain in the middle, neither exceeding nor falling below their targets, and would stay safely in that position to avoid inspection or supervision from auditors, inspectors or higher authorities (Personal Communication with Simon Delay, 2015). According to Inside House (2016), in the case of UK housing organisations, unambitious average syndrome refers to a mediocre average since there is nothing to push units above the target and they tend to remain close to mediocrity, as noted by Ms Taylor (cited in Inside Housing, Out of Commission, 2016):

... what Ms Taylor calls the 'unambitious average' that is the concern. 'There will be nothing to push them anymore,' she says. 'It will be easier to get away with mediocrity now,' agrees...(Inside Housing, 2016)

Simply put, in the context of UK practice, the syndrome refers to units in the public sector which have no motivation to improve their performance far beyond targets in the league table model, despite them having the ability to do so. In other words, performance management seems relatively unimportant as a means of motivating units whose current achievement may exceed targets, yet it is very important for units whose current achievement falls well below targets. Targets are also not overly important for units whose current performance is close to (surrounding) targets since they are comfortable and prefer to remain in this area.

However, unlike the practice in the UK, the concept of an unambitious average in this research is modified to reflect MSS, in which a particular set of minimum standards must be met. Thus, the following hypotheses related to unambitious average syndrome are tested here:

1. Those units whose current status/progress of achievement is far above the standards maintain an average level of performance, at a point just exceeding the standard. This level is below their potential real performance based on their current capacity. This is done to avoid inspection or supervision since any exceptionally good or bad performance is more likely to be picked up by an auditor inspector and higher authorities. Performance management is less important to those units whose current performance slightly exceeds the standard.

2. Public sector units are motivated to improve their performance when their status or progress falls either slightly below or well below the standard. They are motivated to improve their performance to just achieve slightly exceed the standard and maintain a position at or close to their standard as a means of avoiding audit inspection.

\section{Design and Methodologies}

In seeking to answer the research questions, a 'multiple and parallel case study' design was set. This method uses several case studies that were observed at the same time and uses a qualitative approach for data collection and analysis. This design also provides a snapshot

\footnotetext{
1 The ratchet effect explains why public managers who know their targets for next year will be based on last year's performance have an incentive not to exceed the target. The threshold effect involves a situation in which top-performing public managers have an incentive to lower their performance to achieve a target by aligning their performance with that of an average performer, even though they are capable of achieving a higher target. The distortion effect refers to a public manager who is able to legitimately meet a target but who instead seeks to achieve it through the manipulation of data, gaming or output distortion.

${ }^{2}$ While reckless bureaucrats aim at inflating data to maximise points, prudent bureaucrats report figures that are more normal than the real data.
} 
since the qualitative or semi-structured interview data were captured during one particular period of time, between 2015 and 2016. For data collection, semi-structured interviews were conducted with 80 individual interviewees, made up of the following individuals: 20 participants from central government across nine Indonesian technical ministries; 47 participants from local governments comprising Heads of Regions (Mayor/Head of Districts), members of local parliament and local technical agencies and providers in eight districts and cities; and 13 academicians, scholars and experts.

Utilising purposive sampling, eight districts and cities were chosen based on two considerations: the performance level of those districts or cities based on the Evaluation of Performance of Regional/Local Governance, or Evaluasi Kinerja Penyelenggaraan Pemerintahan Daerah (EKPPD), as published by the Indonesian Ministry of Home Affairs, and the fiscal capacity of each district/city, as published by the Indonesian Ministry of Finance. This also considers the characteristics of the areas in the form of Java (more developed) or out of Java (less developed), as presented in Figure 3 below. In addition to this, snowball sampling was also used to select informants/interviewees in central and local government.

Figure 3. Selection of 8 (eight) case studies using purposive sampling

\begin{tabular}{|l|l|l|l|l|}
\hline \multirow{2}{*}{} & \multicolumn{2}{|c|}{ Java } & \multicolumn{2}{c|}{ Out of Java } \\
\cline { 2 - 5 } & \multicolumn{1}{|c|}{ Cities } & \multicolumn{1}{c|}{ Regencies } & \multicolumn{1}{c|}{ Cities } & \multicolumn{1}{c|}{ Regencies } \\
\hline High Performance & $\begin{array}{l}\text { City of Depok } \\
\text { (Province of West } \\
\text { Java) }\end{array}$ & $\begin{array}{l}\text { District of Sleman, } \\
\text { (Province of } \\
\text { Jogjakarta) }\end{array}$ & $\begin{array}{l}\text { City of Denpasar } \\
\text { (Province of Bali) }\end{array}$ & $\begin{array}{l}\text { District of } \\
\text { Batanghari } \\
\text { (Province of } \\
\text { Jambi) }\end{array}$ \\
\hline Low Performance & $\begin{array}{l}\text { City of Bekasi } \\
\text { (Province of West } \\
\text { Java) }\end{array}$ & $\begin{array}{l}\text { District of } \\
\text { West Bandung } \\
\text { (Province of West } \\
\text { Java) }\end{array}$ & $\begin{array}{l}\text { City of Padang } \\
\text { Sidempuan } \\
\text { (Province of North } \\
\text { Sumatera) }\end{array}$ & $\begin{array}{l}\text { District of } \\
\text { Southwest Sumba } \\
\text { (Province of East } \\
\text { Nusa Tenggara) }\end{array}$ \\
\hline
\end{tabular}

\section{Results and Discussions}

This section looks at whether or not MSS influences the motivation of local governments and empirically examines its link with unambitious average syndrome. The analysis is based on secondary data on the achievement of MSS standards in the health sector in eight districts and cities in addition to the results of interviews which were qualitatively analysed through thematic analysis as suggested by Braun and Clarke (2006).

\subsection{The Influence of MSS on the Motivation of Local Governments in Service Delivery Performance in the Health Sector}

Based on their achievement of the standards of MSS, the districts/cities can be classified into three categories. The first category contains local governments whose current achievement far and slightly exceeds the MSS standards (above 87.5\%). Examples of the districts or cities in this category are the District of Sleman, with a current achievement of $97.5 \%$, and the City of Denpasar, with $89.8 \%$. The second category contains local governments whose current achievement status/progress falls just below the standards and includes the City of Bekasi, with a rate of $82.41 \%$, the City of Depok $(81.31 \%)$ and the District of Batanghari $(76.45 \%)$. Finally, the third category contains local governments whose current level of attainment falls well below the standard, including the Districts of West Bandung and Southwest Sumba and the City of Padang Sidempuan, whose current levels of achievement are $63.2 \%, 39.6 \%$ and $45.56 \%$, respectively. The achievements of each district or city across six basic health sector indicators in comparison to the standards can be seen in Figure 4 below.

Based on these figures and combined with the information obtained from the interviews through thematic analysis, MSS seems to motivate improvements in performance among the local governments in the second category, whose current achievement falls just below the 
standard. Some local governments such as the City of Depok, City of Bekasi and the District of Batanghari are motivated to exceed the standard although they do not perceive there to be any incentive for them to do so.

These three local governments are motivated to maintain their performance at a level slightly above the standard or at least close to it in order to avoid scrutiny from higher authorities during coordination meetings. They will seek to maintain this position since they feel safe in the middle and effectively avoid inspection from both auditors and provincial and central government. As such, the empirical findings reveal that MSS is important to these local governments, as evidenced in the following extract from the interviews conducted with local government officials in the City of Bekasi:

... It seems that our concern about being embarrassed by our Mayor in front of other local technical agencies has become our motivation to achieve the standards of MSS although we believe there will be no enforcement from him. Some of the indicators in MSS have been achieved by us and only a few have yet to be accomplished. Our current position is near the standards so it would be embarrassing for our Mayor if we could still not close this small gap. We keep our spirit to achieve the standard in the short time. If we could pass or exceed it, it would be terrific... (Local Health Agency, City of Bekasi, 2016)

Figure 4. Achievement of the MSS standards by the 8 cities/districts across 6 health sector indicators compared to the standards, 2005

\section{Achivement on MSS Year 2015}

in 6 Indicators of Health Sector

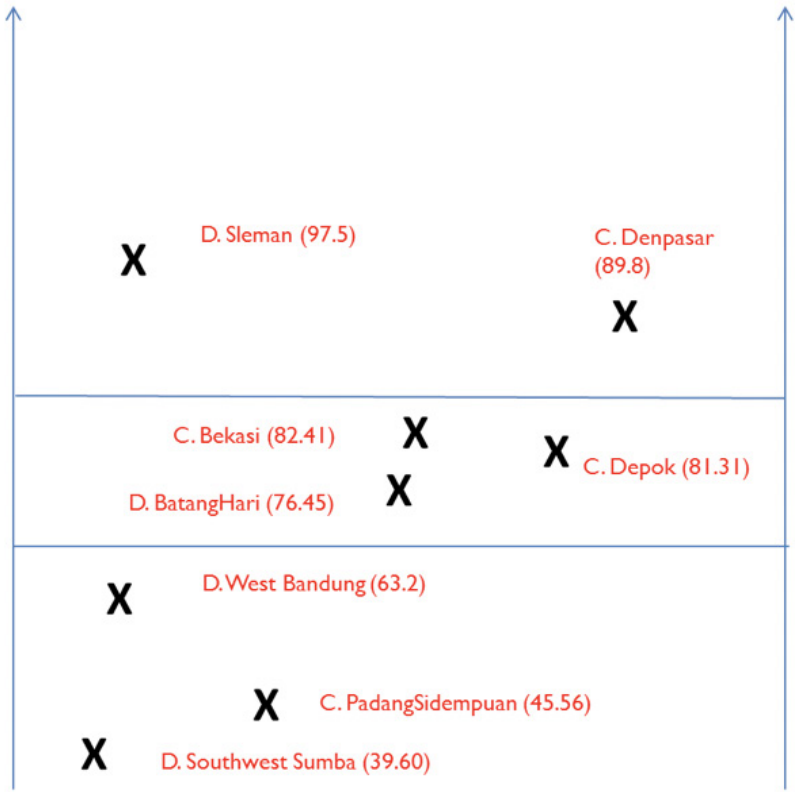

Standards on MSS

(87.5)

Source: Adapted and modified from Bank Data of the Indonesian Ministry of Health: 2016 Module of Indicators on MSS

However, MSS does not seem to motivate those whose performance is either well or slightly above or well below the standards, that is, those districts/cities in the first or third categories. Firstly, those local governments whose current achievement is far above the standard, such as the District of Sleman and City of Denpasar, are not motivated to continually improve their performance once they have passed the standards. MSS seems less important to them since they have already achieved the required standards and there is no further incentive for them to continually improve their performance. Thus, they maintain an average level of performance despite being able to achieve more, thereby avoiding a situation in which an extraordinary performance attracts the attention of higher authorities. 
Instead of improving their achievement against the MSS standards, they pay attention to other areas as types of quality assurance, such as innovation and accreditation. This is evident in the following extract from an interview with members of local government in the District of Sleman.

... In most sectors in this district, the achievement of indicators has been above the standards on MSS. In the education sector, for instance, the ratio of teachers to students and the fulfilment of numbers for primary and junior high schools from the resident areas are more than that required by the central government. There is no point in them continually improving their performance since they have already far exceeded the standards. To go higher would mean becoming an attraction for the central government to demand achievement. Thus, their focus is currently again not about MSS but is on the achievement of Human Development Index (HDI), school accreditation and innovations in education... (Organisation Bureau, Regional Secretary District of Sleman, 2015)

Secondly, those local governments whose current performance falls far below the standards, such as the District of Southwest Sumba and the City of Padang Sidempuan are not motivated to improve their performance in delivering services. This is reflected by their lower motivation to achieve the MSS standards. They may in some cases be willing to improve their performance to just above the standards, but they have no capacity to do this. The gap between the capacity required to pass the standards and their current capacity is too large. In other words, for this category of local government, MSS seems less important, and this was supported by government officers in the City of Padang Sidempuan

... Honestly, MSS is very useful for us. It gives a clear clue to what local governments have to do to deliver better services to people. While people are happy about the services we deliver, we are motivated to improve our performance more and more. However, the classic problem appears. Although we have high motivation, we cannot implement it since we do not have any funds. Our local budget is never sufficient... (Organisation Bureau, Regional Secretary, City of Padang Sidempuan, 2016)

\subsection{Unambitious Average Syndrome in the Practice of Indonesian MSS}

The next question examines whether the influence of MSS on the performance of local government in delivering services as it is discussed above fits or could at least be explained by the concept of the unambitious average syndrome. Firstly, from the point of this view among those units whose current achievement far exceeds the standards it may be assumed that they are not highly motivated to continually improve their performance once they have achieved the standards, in order to avoid attracting the attraction of auditors/supervisors. There is no point in or incentive for performing at a higher level; thus, they maintain an average performance just slightly above the standards.

In the case of MSS, a similar explanation is found when looking at the cases of the District of Sleman and to some extent to the City of Denpasar. This fits with the idea of an unambitious average syndrome whereby performance management is neither sufficiently important nor significant to continue influencing local governments once they have reached the required standards. Empirically, however, there is a slightly extended explanation in the case of MSS. The local governments have no motivation to reach a higher level since they have one forward leap on orientation from standards to other types of quality assurances such as innovation and accreditation, although some explanations in relation to unambitious average syndrome, such as avoiding the attention of auditors and higher authorities as well as having no incentive, are also found.

Secondly, for local governments in the second category, that is, those whose current achievement falls either just below or close (surrounding) to the standards, performance management is empirically shown to be an important or significant influence. The explanations for local governments in this category are a good fit with the notion of an unambitious average syndrome. It can be seen that MSS is important to the local governments in this category, such as the District of Batang Hari, City of Depok and City of Bekasi. They are motivated to just meet the standards since they would feel ashamed if they did not achieve them and would wish to avoid 'informal warnings' from the Head of Regions. Yet, they also consider there to be no incentive or even strong enforcement from auditors and higher authorities. By just meeting the standards and remaining in the middle, they will at least feel safe from the attention of auditors or higher authorities because they have formally complied with the 
performance level mandated by the regulations.

Finally, for those local governments in the third category, whose current achievement falls well below the standards, the empirical findings reveal a different conclusion in relation to the concept of the unambitious average syndrome. While the hypothesis or idea of the unambitious average notes that standards are important in the public sector, it is found empirically that MSS, as a set of standards, is neither important nor relevant to the motivation of local governments such as the District of West Bandung, City of Padang Sidempuan and the District of Southwest Sumba to improve their performance in delivering services. Despite being initially eager to meet and exceed the standards, these local governments have since become demotivated and are not able to exceed the standards given the current state of their financial and human resource capacities.

This also serves as a criticism of the idea of the unambitious average syndrome, in which it is assumed that all units operate with the same level of capacity. A comparison of the hypotheses related to the unambitious average syndrome and the empirical evidence in the case of MSS can be seen in Figure 5 below.

Figure 5. Comparison between the hypotheses and empirical findings

\begin{tabular}{|l|l|l|}
\hline Status of Achievement of MSS & \multicolumn{1}{|c|}{ Adapted Hypothesis } & \multicolumn{1}{|c|}{$\begin{array}{c}\text { Empirical Findings of MSS } \\
\text { Practice }\end{array}$} \\
\hline $\begin{array}{l}\text { Far and Slightly Above Stan- } \\
\text { dards (1st Category) }\end{array}$ & $\begin{array}{l}\text { Less important/Less Signifi- } \\
\text { cant/Less Relevant }\end{array}$ & $\begin{array}{l}\text { Less important/Less Signifi- } \\
\text { cant/Less Relevant }\end{array}$ \\
\hline $\begin{array}{l}\text { Slightly Below Standards (2nd } \\
\text { Category) }\end{array}$ & Important/Significant/ Relevant & Important/Significant/ Relevant \\
\hline $\begin{array}{l}\text { Far Below Standards (3rd } \\
\text { Category) }\end{array}$ & Important/Significant/ Relevant & $\begin{array}{l}\text { Less important/Less Signifi- } \\
\text { cant/Less Relevant }\end{array}$ \\
\hline
\end{tabular}

Source: Author's Analysis

\section{Conclusion}

In conclusion, the two research questions have been answered. Firstly, in relation to 'what is the influence of MSS on the motivation of public sector agencies to improve their performance in delivering services?' the empirical findings reveal a varied influence of MSS on the motivation of local governments, as public-sector agencies, to improve their performance in delivering services. MSS seems only to be an important or relevant for those local governments whose current achievement against the MSS standards is either slightly below or close to (surrounding) the standards. They are motivated and meet the standards in order to not feel ashamed and to avoid 'informal warnings' from the Head of Regions. Three local governments fell within this second category, the District of Batanghari, City of Bekasi and City of Depok.

Nevertheless, MSS seems less important to those local governments whose current achievement either slightly and far exceeds or falls well below the standards, that is, those in the first and third category. For those local governments whose current achievement far exceeds the standards, such as the City of Denpasar and the District of Sleman, they have no motivation to perform at a higher level. They maintain an average level of performance despite being able to perform better. Additionally to those local governments whose current achievement falls far below the standards, such as the District of West Bandung, City of Padang Sidempuan and the District of Southwest Sumba, have no capacity to meet/exceed the standards despite them being keen to do so. As a result, they are not motivated and there is no form of incentive or enforcement to encourage them to continually improve their performance in delivering services.

Furthermore, in answer to the second research question of 'how far does the concept of unambitious average syndrome explain the outcomes attained?', it is empirically found that while the influence of MSS on the motivation of local governments to deliver services hardly fits with the notion of an unambitious average syndrome, it only fits the local governments in 
the second category, that is, those local governments whose current achievement is slightly below or close to (surrounding) the standards/targets. In this category, both the idea and concept of the unambitious average and the empirical findings from these cases of MSS show that performance management is important or significantly influences the motivation of units in the public sector to improve their performance.

However, for local governments in the first and third categories, whose current achievement is either slightly and far above or below the required standards, the concept of the unambitious average syndrome does not seem to fit. Thus, there needs to be an extended explanation in the case of MSS in relation to the current idea of this syndrome. For those local governments whose performance slightly and far exceeds the standards, a slightly different explanation relates to the shift in orientation from MSS to other types of quality assurance. For those with a performance well below the standards, the explanation not captured by the concept of the unambitious average syndrome is related to low capacity. It thus provides a correction to the fact that the unambitious average syndrome does not take into account the capacity of units in the public sector. Further to this, it is also added that there is no incentive or even strong enforcement from auditors and higher authorities.

Finally, this research has implications for the design of current standards and it presents a number of options. Firstly, the use of higher standards to endorse local governments whose achievement exceeds the standard may yet be influential in improving their motivation. Secondly, would be to lower the overall standards with a view to increasing the chances of underperforming local governments achieving them. Another consideration could be given to the application of different standards to each local government category, potentially in the form of asymmetric standards. The final option is the use of progressive standards, whereby future standards can be adjusted and kept near current performance levels. Each design would have its own policy implications and would, of course, require further research. 


\section{References}

Aspinall, E., and Fealy, G. (2003) Introduction: decentralisation, democratisation and the rise of local. In Aspinall, E., and Fealy, G. (ed.) Local power and politics in Indonesia: democratisation and decentralisation. Singapore: Institute of Southeast Asian Studies, pp. 79-92.

Behn, R. D. (2003) Why measure performance? different purposes require different measures. Public Administration Review. 63 (5): 586-606.

Bevan, G., and Hood, C. (2006) What measured is what matters: targets and gaming in the English public health care system. Public Administration. 84 (3): 517-538.

Bouckaert, G. (1995). Measuring quality. In Politt, C., Bouckaert (eds) Quality improvements in European public services: concept, case and commentary. London: Sage.

Braun, D., and Guston, D. H. (2003) Principal-agent theory and research policy: an introduction. Science and Public Policy. 30 (5): 302-308.

Braun, V., and Clarke, V (2006) Using thematic analysis in psychology. Qualitative Research in Psychology. 3 (2): 77-101.

Burgess, S., Propper, C., Ratto, M., et al. (2012) Incentives in the public sector: evidence from a government agency. Discussion Paper Series, Forschungsinstitut zur Zukunft der Arbeit, No. 6738. Available in http://hdl.handle.net/10419/62541

Coleman, J. S. (1990) Foundations of social theory. Harvard: Harvard University Press.

Crowther, D., and Green, M (2004). Organisational theory. London: Chartered Institute Personnel and Development.

De Bruijn, H. (2007) Managing performance in the public sector. 2nd ed. London: Routledge.

Department of Health (2002) Fostering services National Minimum Standards: fostering services regulations. The United Kingdom: Secretary State for Health.

Eide, O. F. (1972) Minimum service standards. Journal American Water Works Association. 64 (5): 295-299

Ferrazzi, G. (2005) Obligatory functions and minimum services standards for Indonesia regional government: searching for a model. Public Administration and Development. 25 (2): 227-238.

Firman, T. (2003) Potential impacts of Indonesia's fiscal decentralization reform on urban and regional development: towards a new pattern of spatial disparity. Space and Polity. 7 (3): 247-271.

Friedman, J (2002). Minimum service standards: current status and planned activities at the Ministry of Home Affairs. Jakarta: Research Triangle Institute Perform Project.

Gaster, L. (1995) Quality in public services: manager's choices. Buckingham: Open University Press.

Greenberg, J. (2011) Behaviour in organizations. 3rd (ed) global edition. Edinburgh: Pearson Education Limited.

Haryanto, A. (2010) Improving service quality of District Education Offices (DEO) in Indonesia decentralized education system. Unpublished PhD Thesis. The School of Management, College of Business, RMIT University. Available from https:// researchbank.rmit.edu.au/eserv/rmit:9481/Haryanto.pdf [Accessed June 5, 2015]

Heinrich, C. J., and Marschke, G. (2010). Incentives and their dynamics in public sector performance management systems. Journal of Policy Analysis and Management. 29 (1): 183-208.

Hood, C. (2006). Gaming in targetworld: the targets approach to managing British Public Services. Public Administration Review. 66 (4): 515-521.

Huczynski, A., and Buchanan, D. (1991) Organizational behaviour. 2nd ed. Hertfordshire: Prentince Hall International.

Hughes, O. (2003) Public management and administration: an introduction. 3rd Ed. Basingtoke: Palgrave Macmillan.

Inside Housing (2016) Out of Commission [Available from http://www.insidehousing.co.uk out-of-commission/6517659.article on December 12th, 2016]

Jacobides, M. G., and Croson, D. C. (2001) Information policy shaping the value of agency relationships. Academy of Management Review. 26 (2): 202-223.

Kalgin, A. (2016). Implementation of Performance Management in Regional Government in 
Russia: Evidence of Data Manipulation. Public Management Review. 18(1): 110-138. Laffont, J. J., and Martimort, J. J. (2009) The theory of incentives: the principal-agent model. Princenton: Princeton University Press.

Maynard, A. (2011) Reforming provider behaviour through incentives: challenges and reflections from the UK experience? In Jalilian, H., and Sen, V. (Eds). Improving health sector performance: institutions, motivations and incentives, the cambodia dialogue. Singapore: Institute of Southeast Asian Studies, p. 19-44.

Meyer, M. W., \& Gupta, V. (1994). The performance paradox. Research in organizational behaviour. 16 (1994): 309-369.

Ministry of Health (2008). Ministry Health Decree Number 828/Menkes/SK/IX/2008 on the technical guidance in the implementation of MSS in the health sector in districts and cities (Keputusan Menteri Kesehatan Nomorr: 828/Menkes/SK/IX/2008 tentang petunjuk teknis Standar Pelayanan Minimal bidang kesehatan kabupaten/kota). Jakarta: Indonesian Ministry of Health. Available at: http://www.kinerja.or.id/pdf ec65ade6-74d0-4046-bd2a-abf58d43c180.pdf (Accessed: 5 June 2017)

Ministry of Health (2016). Data Bank of Health in Indonesian District an City: Module of Indicators on MSS (Bank Data Kesehatan Kabupaten/Kota: Modul Indikator Standar Pelayanan Minimal). Jakarta: Indonesian Ministry of Health. Available at: http:// www.spm.depkes.go.id/index3.php. (Accessed: 4 April 20170)

Mohammad, I. (2007) Minimum service standards as public service improvement efforts: the Indonesian experience. Presented in Eropa Seminar in Service Quality in Public Sector: An Outcome-Based Approach. Tehran: 18-22 November 2007. Available from http://unpan1.un.org/intradoc/groups/public/documents/EROPA/ UNPAN029263.pdf [Accessed 5 June 2015]

Moorhead, G., and Griffin, R. W. (2012). Managing organizational behaviour. 10th Ed. Australia: South Western Cengage Learning.

Mullins, L. J. (2008) Essential of organisational behaviour. 2nd Ed. Harlow, England: Prentice Hall.

Mutaqin, T. (et al. 2016) The impact of decentralization on educational attainment in Indonesia. In Holzhacker, R. L., Wittek, R., and Woltjer, J. (Eds.). Decentralization and Governance in Indonesia. Switzerland: Springer International Publishing, p.79-104.

Peters, B. G. (2001) The politics of bureacracy. 5th ed. London: Routledge

Plant, T. (2006) The performance measurement paradox in local government management. Public Management. 88 (4): 16-20

Schiavo, L. L. (2000) Quality standards in the public sector: difference between Italy and the UK in the citizen's charter initiative. Public Administration. 78 (3): 679-698.

Schulze, G. G., and Sjahrir, B. S. (2014) Decentralization, governance and public service delivery. In Hill, H (ed). Regional Dynamics in a Decentralized Indonesia. Singapore: Institute of Southeast Asian Studies, p. 187-207.

Seddon, J. (2008) Systems thinking in the public sector: the failure of the reform regime and a manifesto for a better way, The United Kingdom: Triachy Press.

Smith, P. (1995) On the unintended consequences of publishing performance data in the public sector. International Journal of Public Administration. 18 (2): 277-310.

Strategic Asia. (2013) Decentralization assessment report. Jakarta: UNDP and Strategic Asia.

Talbott, C. (2010) Theories of performance: organizational and service improvement in the public domain. The United Kingdom: Oxford University Press.

Taylor, R. (1911) The Political Prophecy in England. New York: Columbia University Press.

Van Dooren, W., and Bouckaert, G., and Halligan, J. (2010) Performance management in the public sector. London: Routledge.

Van Thiel, S., \& Leeuw, F. L. (2002). The performance paradox in the public sector. Public Performance \& Management Review. 25(3): 267-281.

Waterman, R. W., and Meier, K. J (1998) Principal-agent models: an expansion? Journal of Public Administration Research and Theory. 8 (2): 173-202.

Williamson, C. (1992) Whose standards? consumer and professional standards in health care. Buckingham: Open University Press. 